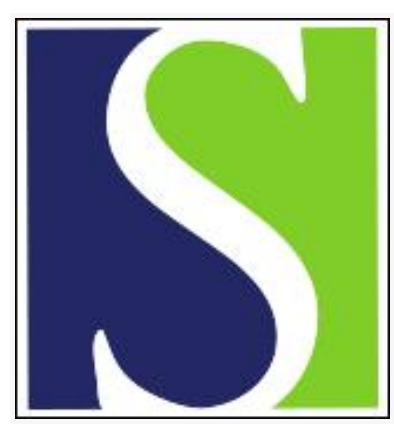

Scand J Work Environ Health 1977;3(2):104-107

https://doi.org/10.5271/sjweh.2788

Issue date: Jun 1977

\title{
Brain and blood lead in acute intoxication.
}

by Savolainen H, Kilpiö J

Key terms: acute intoxication; blood lead; blood-brain barrier; brain lead; lead intoxication

This article in PubMed: www.ncbi.nlm.nih.gov/pubmed/882858

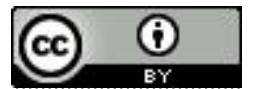




\title{
Brain and blood lead in acute intoxication
}

\author{
by HEIKKI SAVOLAINEN, M.D., and JUKKA KILPIÖ, M.Sc. ${ }^{1}$
}

\begin{abstract}
SAVOLAINEN, H. and KILPIO, J. Brain and blood lead in acute intoxication. Scand. $j$. work environ. \& health 3 (1977) 104-107. Administering lead acetate in drinking water to adult male rats resulted in an elevated lead content in blood and brain during 11 subsequent days. The brain and blood lead contents were proportional to each other although the interdependency changed according to the cumulative dose and equilibration period. The present data indicate that the permeability of the blood-brain barrier towards inorganic lead may be dose-dependent and saturable with high doses of the metal.
\end{abstract}

Key words: blood-brain barrier, blood lead, brain lead, lead intoxication.

Clinical and subclinical lead intoxication remains an important medical problem despite advanced preventive and diagnostic facilities (12). Occupational exposure to lead can be effectively controlled, but environmental lead poses a significant hazard, especially to children $(11,15,16)$.

Intoxication in adults is predominantly characterized by motor polyneuropathy of the upper limbs, while typical intoxication in childhood displays central nervous system symptoms including the hyperkinetic syndrome (6). The manifestations of experimental acute animal poisoning, as well as those in childhood intoxications, may be mediated by a direct toxic effect of lead on neuronal function $(3,4)$, whereas the polyneuropathy of adults may result from Schwann cell changes in the affected nerves (8).

The permeability barrier in the adult central nervous system is an integral function of endothelial cells and adjoining glia

1 Department of Industrial Hygiene and Toxicology, Institute of Occupational Health, Helsinki, Finland.

Reprint requests to: Dr. Heikki Savolainen, Institute of Occupational Health, Haartmaninkatu 1, FIN-00290 Helsinki 29, Finland.
$(5,13)$. A large number of chemical compounds is known to affect the barrier function and render it less selective and freely permeable (17). Many functions of the "blood-brain barrier" are enzymatically mediated and thus display enzyme kinetics (13). This phenomenon led us to investigate the relationship between the lead content of blood and brain after cumulative peroral lead acetate intake to establish eventual dose-dependent changes in the brain uptake of the metal.

\section{MATERIALS AND METHODS}

Sixteen adult male rats of the SpragueDawley strain with an average weight of $238 \pm 13 \mathrm{~g}( \pm \mathrm{SD})$ were given free access to drinking water that contained lead $(10 \mathrm{~g} / 1)$. When the lead solution was prepared, the appropriate amount of lead acetate was dissolved in water and the solution was buffered to $\mathrm{pH}$ 6.6. The water consumption was measured daily.

Four rats were killed by decapitation 2, 4 and 7 days after the beginning of the experiment; 1 rat was decapitated on the 9th and 2 rats on the 11 th day of the experiment. The animals were bled at the time of sacrifice, and the blood specimens 
were collected in heparinized tubes. One rat died spontaneously on the 9th day, and no blood sample could be drawn from it. The cerebral hemispheres of each animal were dissected in an ice bath, and the samples were stored at $-70^{\circ} \mathrm{C}$ until analysis.

The blood lead analysis was performed with a Perkin-Elmer 400 atomic absorption spectrophotometer equipped with a Perkin-Elmer HgA-74 flameless atomizing unit as well as with an AS-1 Auto-Sampler automatic sample feeding apparatus. Each blood sample was diluted with deionized water (1:20 and 1:40), and the dilutions were subjected to direct analysis (7). Both dilutions gave uniform results with a variation of 0.3 to $6.4 \%$. The general coefficient of variation was $2.0 \%$.

The brain lead content was analyzed after the solubilization of the brain sample in tetramethyl ammonium hydroxide (9). Internal standards were used with the latter samples so that matrix-dependent changes in the atomization of lead could be avoided. Otherwise the analysis was carried out in the same manner as the blood lead analysis. The coefficient of variation in the analysis of brain lead was $5.8 \%$.

\section{RESULTS}

The rats were conspicuously inactive after the first 2 days of the beginning of the experiment. They were reluctant to make active movements after 1 week of exposure and were lethargic during the 2nd week, the spontaneous death of one animal occurring on the 9th day. The water consumption per animal declined as the cumulative lead dose increased. The water intake was $140 \pm 26 \mathrm{ml} /$ animal ( $\pm \mathrm{SD}$, $\mathrm{N}=16$ ) on the first day of exposure, $8.2 \pm 3 \mathrm{ml}( \pm \mathrm{SD}, \mathrm{N}=16)$ on the second day, and it remained thereafter at a daily level of 8 to $23 \mathrm{ml} /$ animal.

The cumulative lead ingestion on the second day was $4.2 \mathrm{mg} / \mathrm{g}$ of body weight, on the fourth day 4.7 , on the seventh day 4.8 , on the ninth day 5.9 and on the 11th day $8.2 \mathrm{mg} / \mathrm{g}$ of body weight. The brain lead content was proportional to that of blood lead although this interdependency changed according to the ingested lead and was a function of the observation time after the beginning of the lead consumption (fig. 1). A lead dose of $4.2 \mathrm{mg} / \mathrm{g}$ of body weight in 2 days caused an increase in brain lead content with a linear function of $y=0.001 x+0.20$ (linear regression 0.99), where $\mathrm{y}$ is brain lead and $x$ blood lead. The interdependency changed after a lead intake of $4.7 \mathrm{mg} / \mathrm{g}$ during 4 days, the function being described by the equation $\mathrm{y}=0.02 \mathrm{x}-1.93$ (linear regression 0.93). In overwhelming

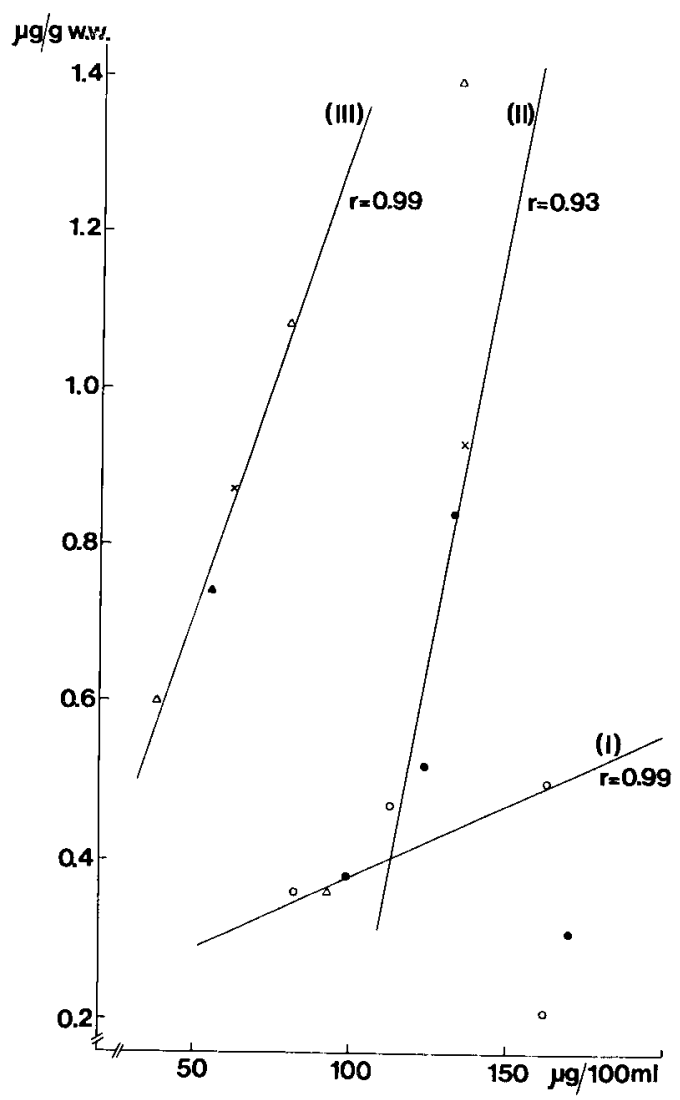

Fig. 1. The increase of rat brain lead (ordinate) as a function of blood lead (abscissa). Three linear functions can be found. The first line (I) follows equation $\mathrm{y}=0.001 \mathrm{x}+0.20$, the second (II) $\mathrm{y}=0.02 \mathrm{x}-1.93$ and the third (III) $\mathrm{y}=0.01 \mathrm{x}-0.13$. Note the changes in brain vs. blood lead function according to the cumulative dose and equilibration time. Only three plotted values fall outside the calculated regression lines. ( $\mathrm{r}=$ = linear regression; $0=$ decapitated 2 days after the beginning of lead ingestion; - killed 4 days, $\triangle=$ killed 7 days, $\Delta=$ killed 9 days, and $x=$ killed 11 days after the start of the experiment) 
lead intoxication with a lead intake of 4.8 to $8.2 \mathrm{mg} / \mathrm{g}$ of body weight during 7 to 11 days the interdependency followed a third linear function, $\mathrm{y}=0.01 \mathrm{x}-0.13$ (linear regression 0.99).

\section{DISCUSSION}

Calculating the daily mean of the blood lead concentrations is not informative, as the absorption of lead from the gastrointestinal tract varies greatly from one animal to another. Therefore the corresponding brain and blood lead contents are compared directly to each other. The present data indicate that the two are proportional to each other in acute intoxication although the interdependency changes according to the dose and equilibration period. One of the three points outside the regression lines corresponds to high brain and blood lead levels, and it is not certain whether the point belongs to line II or line III. As for the two other points with high blood vs. low brain lead, no rational explanation except a possible methodological error can be found.

The resolution of brain vs. blood lead interdependency by three different equations is based on the least deviation of the plotted points from the regression lines. The appearance of a third interdependency (III) in overwhelming intoxication is surprising although it may be explained by a more rapid redistribution of body lead than that in brain and therefore result in proportionally lower blood lead levels.

The changes in the function of brain lead by blood lead may reflect alterations in the so-called blood-brain barrier after lead intoxication. The selective permeability of chemicals in brain is thought to be a capillary-glial function that may be saturable with various chemicals (17). The present observations indicate that the ingestion of approximately $4 \mathrm{mg}$ of lead per gram of body weight during 2 days increases the brain lead content at a much slower rate than the ingestion of $4.7 \mathrm{mg} / \mathrm{g}$ during 4 days. After the dose- and equilibration-dependent saturation of the barrier, blood lead enters the brain more freely, as was detected during the last days of our study. Morphological studies indicate that lead is concentrated primarily in astrocytes and pericytes while neuronal changes prevail at later stages (10).

The theoretical saturation of the permeability barrier occurs at the intersection of lines I and II (fig. 1). In the present study this blood lead content was $112 \mu \mathrm{g} /$ $100 \mathrm{ml}$, which correlates very well with clinical observations on lead toxicity in man (12). The blood lead concentration equates to a brain lead level of $0.4 \mu \mathrm{g} / \mathrm{g}$ on line I. This brain lead concentration is the lowest lead level with changes in potassium-stimulated respiration, while no effect can be detected at the lead level of $0.17 \mu \mathrm{g} / \mathrm{g}$ (6). After collapse of the permeability barrier, and in later phases of lead intoxication, a redistribution of lead may take place in brain as well as in other organs. The increased transport of lead into brain after severe lead intoxication has been demonstrated also indirectly with studies on the transfer of ${ }^{208} \mathrm{~Pb}$ in control and lead-intoxicated animals (14).

Many investigations emphasize the importance of environmental lead in elevated lead absorption in man $(11,15)$, but domestic water lead gives rise only to $25 \%$ of the blood lead of the general population (2). However, lead is readily, although not quantitatively, absorbed in the gastrointestinal tract (1). The administration of lead in drinking water to experimental animals clearly offers advantages in comparison to forced administration, e.g., through intraperitoneal injections or gastric intubations. Most studies with forced lead administration fail to demonstrate the changes in barrier permeability. One such study (4) reports a linear brain and blood lead relationship after a daily intragastric dosage of $155 \mathrm{mg}$ of lead carbonate in guinea pigs during six consecutive days. The blood and brain lead contents of the study clearly follow equation III of our present investigation. Thus the increase in body lead is apparently too rapid in experiments with forced administrations, and such experiments may not necessarily simulate clinical human poisonings.

\section{REFERENCES}

1. ASOKAN, S. K. Experimental lead cardiomyopathy: Myocardial structural changes 
in rats given small amounts of lead. $J$. lab. clin. med. 84 (1974) 20-25.

2. BEATTLE, A. D., CAMPBELL, B. C., MOORE, M. R. and GOLDBERG, A. Bloodlead and domestic water lead. Lancet 2 (1976) $200-201$.

3. BOULDIN, T. W. and KRIGMAN M. R. Acute lead encephalopathy in the guinea pigs. Acta neuropathol. (Berl.) 33 (1975) $185-190$.

4. BOULDIN, T. W., MUSHAK, P., O'TUAMA L. A. and KRIGMAN M. R. Blood-brain barrier dysfunction in acute lead encephalopathy: A reappraisal. Environ. health perspect. 12 (1975) 81-88.

5. BRIGHTMAN, M. W. and REESE, T. S. Membrane specializations of ependymal cells and astrocytes. In: D. B. TOWER (ed.), The nervous system (vol. I). Raven Press, New York, N. Y. 1975, pp. 267-277.

6. BULL, R. J., STANASZEK, P. IM., O'NEILL, J. J. and LUTKENHOFF S. D. Specificity of the effects of lead on brain energy metabolism for substrates donating a cytoplasmic reducing equivalent. Environ. health perspect. 12 (1975) $89-95$.

7. FERNANDEZ, F. J. Micromethod for lead determination in whole blood by atomic absorption, with use of the graphite furnace. Clin. chem. 21 (1975) 558-561.

8. GOLDSTEIN, N. P., MC CALL, J. T. and DYCK, P. J. Metal neuropathy. In: P. K. THOMAS and E. H. LAMBERT (eds.), Peripheral neuropathy. Saunders, Philadelphia, Pa. 1975, pp. 1227-1262.

9. GROSS, S. B. and PARKINSON, E. S. Analysis of metals in human tissues using base (TMAH) digests and graphite furnace

Received for publication: 1976-11-02 atomic absorption spectrophotometer. At. absorpt. newslett. 13 (1974) 107-108.

10. HIRANO, A. and KOCHEN, J. A. Further observations on the effects of lead implantation in rats brains. Acta neuropathol. (Berl.) 34 (1976) 87-93.

11. LANDRIGAN, P. J., FELDMAN, R. G., BAKER, E. L., KOSKI, C. L., HAYES, M. $K$, BERNSTEIN R. and COHEN S. Lead absorption and slowed nerve conduction in children near a lead smelter. Neurology (Minneap.) 26 (1976) 391-392.

12. MELGAARD, B., CLAUSEN, J. and RASTOGI, S. C. Heavy metal levels and deltaamino-levulinic acid dehydrase levels in peripheral polyneuropathy. Acta neurol. scand. 53 (1976) 291-307.

13. OLDENDORF, W. H. Permeability of the blood-brain barrier. In: D. B. TOWER (ed.), The nervous system (vol. I). Raven Press, New York, N. Y. 1975, pp. 279-289.

14. O'TUAMA, L. A., KIM, C. S., GATZY, J. T., KRIGMAN, M. R. and MUSHAK $P$. The distribution of inorganic lead in guinea pig brain and neural barrier tissues in control and lead-poisoned animals. Toxicol. appl. pharmacol. 36 (1976) 1-9.

15. PERKINS, K. C. and OSKI, F. A. Elevated blood lead in a 6-month-old breast-fed infant: The role of newsprint logs. Pediatrics 57 (1976) 213-214.

16. SILBERGELD, E. K. and CHISOLM, J. J. Lead poisoning: Altered urinary metabolites as indicators of intoxication in mice and children. Science 192 (1976) 153-155.

17. STEINWALL, $O$. and KLATZO, I. Selective vulnerability of the blood-brain barrier in chemically induced lesions. J. neuropathol. exp. neurol. 25 (1966) 542-559. 